\title{
STUDI KEANEKARAGAMAN ARTHROPODA TANAH DI AREA KONSERVASI KURA-KURA Manouria emys UNIVERSITAS BENGKULU DAN PENGEMBANGAN PEMBELAJARAN SISWA SMA
}

\author{
Meri Suterisni $^{1}$ *, Bhakti Karyadi ${ }^{2}$, Endang Widi Winarni ${ }^{3}$ \\ ${ }^{1,2}$ Pascasarjana Pendidikan IPA Universitas Bengkulu, Bengkulu \\ ${ }^{3}$ Pascasarjana Pendidikan Dasar Universitas Bengkulu, Bengkulu \\ *Email: merisuterisni44@gmail.com
}

\begin{abstract}
ABSTRAK
Artikel ini terdiri dari dua studi. Studi pertama bertujuan untuk mengetahui Indeks Keanekaragaman Arthropoda pada area Konservasi Kura-kura Manouria emys Universitas Bengkulu .Hasil Studi pertama dikembangkan sebagai bahan ajar Biologi Berbasis Lingkungan di SMA Negeri 1 Ujan Mas Kabupaten Kepahiang Bengkulu. Dalam penelitian pertama dilakukan observasi terhadap hewan Arthropoda dengan mengidentifikasi dan inventarisasi jenis sampai tingkat Ordo.Parameter yang diamati adalah indeks keanekaragaman (H dengan nilai 1,17), kemerataan (E) dengan nilai 0,67, indeks dominansi Arthropoda (C) dengan nilai 1 dan Kepadatan Populasi (KP) 5,761. Hasil penelitian menunjukkan: 1) Jenis Arthrpoda tanah yang ditemukan di Area Konservasi Kura-kura Monuora emys Universitas Bengkulu berjumlah 11 ordo, 2) Keanekaragaman jenis arthropoda tanah yang diperoleh dari Area Konservasi Kura-kura Baning tergolong dalam kategori sedang,3) Spesies yang mendominasi yang tergolong dalam ordo Hymenoptera, dan 4) faktor abiotik pada Area Konservasi Kura-kura Baning termasuk ke dalam kategori normal dengan ekosistem yang seimbang.Perangkat Pembelajaran yang dikembangkan dapat menumbuhkan Keterampilan berpikir kritis peserta didik yang tinggi.
\end{abstract}

Kata kunci: Keanekaragaman, Arthropoda, Area Konservasi, Kura-kura, Manouria emys, Universitas Bengkulu, Keterampilan berpikir kritis.

\section{PENDAHULUAN}

Konservasi merupakan upaya-upaya pelestarian lingkungan dengan memperhatikan manfaat yang dapat diperoleh pada saat ini dan tetap mempertahankan keberadaan setiap komponen lingkungan untuk pemanfaatannya di masa yang akan datang. Dengan kata lain konservasi adalah suatu upaya yang dilakukan manusia untuk dapat melestarikan alam. Dengan demikian kegiatan konservasi meliputi seluruh kegiatan pemeliharaan sesuai dengan kondisi dan situasi lokal maupun upaya pengembangan untuk pemanfaatan lebih lanjut.

Dalam mengembangkan area konservasi diperlukan adanya daya dukung lingkungan artinya keberadaan hewan-hewan lain sebagai satu kesatuan dalam ekosistem perlu diperhatikan termasuk arthropoda tanah yang berperanan sebagai debtrivor yang mempunyai peranan penting dalam ekosistem. Peranan Arthropoda tanah menguraikan serasah menjadi bagian yang halus membentuk humus yang menyebabkan tanah subur yang menyediakan unsur hara yang diperlukan tanaman untuk tumbuh dan berkembang menjadi bahan makanan bagi makhluk hidup seperti kura-kura.

Arthropoda meliputi serangga yang merupakan bagian dari keanekaragaman hayati, yang harus dijaga kelestariannya dari kepunahan maupun penurunan keanekaragaman jenisnya. Serangga memiliki nilai penting antara lain nilai ekologi, endemisme, konservasi, pendidikan, budaya, estetika dan ekonomi (Silviana, 2014). Serangga juga merupakan spesies hewan yang jumlahnya paling dominan diantara spesies hewan lainnya. Tarumingkeng (2003) mengungkapkan bahwa ada sekitar 10 juta spesies serangga yang belum dideskripsikan.

Keberadaan area konservasi ex-situ kurakura di Universitas Bengkulu merupakan salah satu sumber belajar Biologi di SMA yang berbasis lingkungan diharapkan dapat mempermudah pemahaman siswa dalam 
mempelajari materi Ekosistem sub topik komponen-komponen dalam ekosistem.

Pembelajaran secara umum merupakan kegiatan yang dilakukan oleh guru untuk mengubah tingkah laku siswa kearah yang lebih baik . Upaya peningkatan sumber daya manusia yang berkualitas diperlukan strategi belajar mengajar yang mampu memperbaiki sistem pendidikan yang telah berlangsung selama ini. Salah satu tolak ukur keberhasilan seorang guru dalam pembelajaran adalah apabila hasil belajar siswa mencapai hasil belajar yang optimal. Keberhasilan ini sangat bergantung pada kemampuan guru dalam mengelola proses belajar mengajar. Sasaran pembelajaran dengan pendekatan keterampilan proses mencakup pengembangan ranah sikap, pengetahuan dan keterampilan berpikir kritis yang dielaborasi untuk setiap satuan pendidikan.

Keterampilan berpikir kritis dikelompokkan menjadi keterampilan berpikir dasar dan kerampilan berpikir kritis tingkat tinggi.Keterampilan berpikir dasar meliputi menghubungkan sebab akibat, mentransformasi, menemukan hubungan dan menemukan kualifikasi. Sedangkan berpikir kritis tingkat tinggi meliputi pemecahan masalah, membuat keputusan, berpikir kritis dan kreaktif. Berfikir kritis merupakan salah satu tujuan pendidikan maka merencanakan pembelajaran Biologi yang mengembangkan berpikir kritis merupakan keharusan karena pada saat proses belajar siswa akan memperlihatkan pikiran-pikiran dan proses bertanya, membedakan antara observasi dan kesimpulan, memerlukan bukti yang cukup untuk menarik sebuah kesimpulan dan memberikan penjelasan . (Winarni, 2012)

Pengamatan Arthropoda tanah di Area Konservasi Kura-kura menjadikan area tersebut sebagai sumber pembelajaran bagi siswa sehingga perlu dikaji lebih lanjut mengenai kekayaan dan kelimpahan Arthropoda pada ekosistem area Konservasi.

\section{METODE PENELITIAN}

Penelitian ini terdiri dari dua tahapan, yaitu penelitian Keanekaragaman Arthropoda Tanah di area konservasi kura kura Baning (Manouria emys) di belakang gedung Pascasarjana (S2) FKIP Universitas Bengkulu dan penelitian pembelajaran dengan pengembangan model Dick and Carey. Alat yang digunakan dalam penelitian keanekaragaman arthropda tanah, yaitu :pitfall trap, mikroskop, meteran, botol objek dan bahan yang digunakan yaitu formalin, air, detergen, alkohol dan tali plastik. Penangkapan Arthropoda tanahdengan metode purposive sampling, yaitu lokasi area konservasi kura-kura di belakang Gedung Program Pascasarjana (S2) FKIP Universitas Bengkulu. Langkah penelitian dimulai dari pembuatan Plot sebanyak 3 plot yang ukurannya $3 \times 3 \mathrm{~m}$, kemudian meletakkan perangkap jebak atau pitfall trap dengan metode baris, pengamatan dilakukan setiap seminggu sekali, sebanyak empat kali pengamatan untuk menangkap Arthropoda tanah, gelas plastik yang diameter permukaannya berukuran $7 \mathrm{~cm}$, kedalaman $10 \mathrm{~cm}$, yang bagian permukaan perangkap tersebut sejajar dengan permukaan tanah. Air yang telah dicampurkan dengan detergen sebanyak 10 gr dituangkan ke dalam gelas sebanyak $\pm 60 \mathrm{ml}$. Pada lokasi perangkap ini dipasang menyebar dengan menggunakan metode baris dengan 16 buah perangkap dipasang dalam setiap lokasi, sehingga total perangkap jebak adalah 32 buah. Perangkap jebak ini dibiarkan selama 24 jam dan diambil besoknya pada jam yang sama. Sampel yang diambil yaitu Arthropoda yang terperangkap dimasukkan ke dalam botol plastik yang berisi cairan alkohol dan selanjutnya dibawa ke laboratorium SMP N 1 Ujan Mas untuk diidentifikasi. Identifikasi Arthropoda permukaan tanah dilakukan dengan menggunakan mikroskop Binokuler dan mikroskop cahaya, dan diamati ciri morfologi arthropoda tanah tersebut kemudian diidentifikasi menggunakan buku identifikasi Borror (1992). Kunci determinasi serangga Subiyanto dan Sulthoni (1980) di laboratorium kemudian dianalisa sampai tingkat famili.

\section{Prosedur Pengembangan Perangkat Pembelajaran \\ Penelitian ini dilakukan dengan menggunakan model pengembangan research and development menggunakan uji coba skala kecil (Dick \& Carey, 2005) pada kelas X SMA Negeri 1 Ujan Mas Kabupaten Kepahiang, dengan langkah-langkah sebagai berikut: \\ a. Tahap I (Perencanaan) dengan kegiatan antara lain melakukan Identifikasi Tujuan}


Pembelajaran, Analisis materi Pembelajaran, Analisis Karakteristik Siswa, Mengembangkan Strategi Pembelajaran, menyusun dan mengembangkan Perangkat Pembelajaran (Silabus, RPP, LKPD, Instrumen dan Rubrik Penilaian Keterampilan Berpikir Kritis),

b. Tahap 2 (Validasi) Pada tahap ini perangkat perangkat pembelajaran yang telah disusun dan dikembangkan dilakukan validasi oeh ahli dan praktisi (Dosen dan Guru senior). Adapun Perangkat pembelajaran yang divalidasi adalah Silabuss, RPP, LKPD dan Instrumen Penilaian.

c. Tahap 3 (Revisi) Pada tahap ini akan dilakukan revisi atau perbaikan terhadap Perangkat Pembelajaran yang telah di validasi oleh validator.

d. Tahap 4 (Uji coba Skala kecil) Pada Tahap ini dilakukan uji coba pembelajaran yang dilaksanakan di SMA Negeri 1 Ujan Mas yang berjumlah 20 orang siswa. Kegiatan ujicoba ini bertujuan untuk mengukur Kemampuan berpikir kritis siswa dari aspek kognitif dan aspek kinerja dengan menggunakan dimensi dan indikator Ennis (2011) dalam winarni (2012).

\section{HASIL DAN PEMBAHASAN}

\section{Keanekaragaman Arthropoda Tanah}

Tabel 1. Keanekaragaman arthropoda tanah di area konservasi kura-kura Manouria emys

\begin{tabular}{|l|l|l|c|l|}
\hline NO & \multicolumn{1}{|c|}{$\begin{array}{c}\text { Arthropoda } \\
\text { tanah (ordo) }\end{array}$} & \multicolumn{1}{|c|}{ Nama Jenis } & $\begin{array}{c}\text { Jumlah } \\
\text { Individu }\end{array}$ & $\begin{array}{c}\text { Peranan dalam } \\
\text { Ekologi }\end{array}$ \\
\hline 1 & Hymenoptera & $\begin{array}{l}\text { Semut hitam } \\
\text { kecil }\end{array}$ & 153 & Predator \\
\hline besar & $\begin{array}{l}\text { Semut rang- } \\
\text { rang }\end{array}$ & 135 & Predator \\
\hline 2 & Dermaptera & Species x & 24 & Predator \\
\hline 3 & Diptera & Lalat & 11 & Herbivor \\
\hline & & Nyamuk & 13 & \\
\hline 4 & Araneae & Laba-laba & 5 & Predator \\
\hline 5 & Colembola & Spesies y & 41 & Dekomposer \\
\hline 6 & Acarina & Tungau & 4 & Parasit \\
\hline 7 & Orthoptera & Jangkrik & 4 & Herbivor \\
\hline 8 & Scolopendomorpha & Kelabang & 1 & Predator \\
\hline 9 & Spirobolida & Ulat kaki seribu & 1 & Herbivor \\
\hline 10 & Coleoptera & Kumbang & 3 & Detrivor \\
\hline 11 & Blattaria & Kecoa & 2 & Detrivor \\
\hline & Jumlah & & 463 & \\
\hline$K$
\end{tabular}

Keterangan: Penentuan kunci determinasi kelas insecta disusun oleh Subianto dan A.Sulthoni
(1980). Pengenalan serangga dasar Borror dkk (1992)

Berdasarkan data-data pada tabel diatas diperoleh hasil 463 individu dengan 11 ordo. Jumlah individu yang terbanyak yang diperoleh adalah ordo Hymenoptera, Dermaptera, dan colembola. Ordo hymenoptera memiliki kebiasaan berkoloni sehingga saat dilakukan pengambilan dengan mengunakan pitfall trap diperoleh jumlah terbesar dihuni oleh famili Formicideae contohnya: semut yang dapat hidup di semua tempat, seperti juga dalam penelitian Suwondo (2015) menyatakan ordo Hymenoptera ditemukan didaerah persawahan, hutan, dan daerah terbuka sehingga jumlahnya sangat banyak, selain itu ketersedian bahan makanan serta habitat yang cocok juga mempengaruhi jumlah semut yang ada diarea konservasi. Sedangkan ordo serangga tanah lainnya orthoptera, coleoptera, diptera, Scolopendromorpha, dan Spirobolida ditemukan dalam jumlah sedikit karena bersifat mobile atau tidak permanen sehingga sering berpindah tempat (Suwondo 2015). Jumlah individu Collenbola berjumlah 41 individu yang sangat diperlukan dalam ekosistem karena peranannya sebagai dekomposisi. Ordo Dermaptera di area konservasi kura-kura baning Universitas Bengkulu menduduki urutan ketiga dengan jumlah 24 individu.

Meskipun fauna tanah khususnya mesofauna tanah sebagai penghasil senyawasenyawa organik tanah dalam ekosistem tanah, namun bukan berarti berfungsi sebagai subsistem produsen. Tetapi, peranan ini merupakan nilai tambah dari mesofauna sebagai subsistem konsumen dan subsistem dekomposisi. Sebagai subsistem dekomposisi

Mesofauna sebagai organisme perombak awal bahan makanan, serasah, dan bahan organik lainnya (seperti kayu dan akar) mengkonsumsi bahan-bahan tersebut dengan cara melumatkan dan mengunyah bahan-bahan tersebut. Mesofauna tanah akan melumat bahan dan mencampurkan dengan sisa-sisa bahan organik lainnya, sehingga menjadi fragmen berukuran kecil yang siap untuk didekomposisi oleh mikrobio tanah (Arief, 2001). 
Analisis Indeks Keanekaragaman (H), Indeks Kemerataan (E), Indeks Dominansi (C) dan Kepadatan populasi Arthropoda Tanah

Tabel 2. Indeks Keanekaragaman $(\mathrm{H})$,Indeks Kemerataan (E), Indeks Dominansi (C) dan Kepadatan populasi Arthropoda Tanah di Area Konservasi Kura-kura Baning Gajah Universitas Bengkulu.

\begin{tabular}{|l|l|c|c|c|c|c|}
\hline $\begin{array}{c}\text { Arthrop } \\
\text { oda } \\
\text { (ordo) }\end{array}$ & $\begin{array}{c}\text { Nama } \\
\text { individu }\end{array}$ & $\begin{array}{c}\text { Jumlah } \\
\text { Individu }\end{array}$ & $\mathbf{H}$ & $\mathbf{E}$ & $\mathbf{C}$ & $\mathbf{K P}$ \\
\hline \multirow{3}{*}{$\begin{array}{l}\text { Hymeno } \\
\text { ptera }\end{array}$} & $\begin{array}{l}\text { Semut hitam } \\
\text { kecil }\end{array}$ & 153 & 0.37 & 0.14 & 0.33045 & 1.8888 \\
\cline { 2 - 7 } & $\begin{array}{l}\text { Semut hitam } \\
\text { besar }\end{array}$ & 66 & 0.28 & 0.11 & 0.14255 & 0.8141 \\
\cline { 2 - 7 } & Semut merah & 135 & 0.36 & 0.14 & 0.29158 & 1.4466 \\
\hline $\begin{array}{l}\text { Dermapt } \\
\text { era }\end{array}$ & Species x & 24 & 0.15 & 0.06 & 0.05184 & 0.2962 \\
\hline Diptera & Lalat & 11 & 0.09 & 0.03 & 0.02376 & 0.1358 \\
\cline { 2 - 7 } & Nyamuk & 13 & 0.10 & 0.04 & 0.02808 & 0.1604 \\
\hline Araneae & Laba-laba & 5 & 0.05 & 0.02 & 0.01080 & 0.0617 \\
\hline $\begin{array}{l}\text { Collemb } \\
\text { ola }\end{array}$ & Spesies y & 41 & 0.21 & 0.08 & 0.08855 & 0.5061 \\
\hline \multirow{2}{*}{$\begin{array}{l}\text { Acarina } \\
\text { Orthoptera }\end{array}$} & Jungau & 4 & 0.04 & 0.02 & 0.00864 & 0.049 \\
\cline { 2 - 7 } & Jangkrik & 4 & 0.04 & 0.02 & 0.00864 & 0.049 \\
\hline $\begin{array}{l}\text { Scolopen } \\
\text { domorph } \\
\text { a }\end{array}$ & Kelabang & 1 & 0.01 & 0.01 & 0.00216 & 0.0123 \\
\hline $\begin{array}{l}\text { Spiroboli } \\
\text { da }\end{array}$ & $\begin{array}{l}\text { Ulat kaki } \\
\text { seribu }\end{array}$ & 1 & 0.01 & 0.01 & 0.00216 & 0.0123 \\
\hline $\begin{array}{l}\text { Coleopte } \\
\text { ra }\end{array}$ & Kumbang & 3 & 0.03 & 0.01 & 0.00648 & 0.0370 \\
\hline Blattaria & Kecoa & 2 & 0.02 & 0.01 & 0.00432 & 0.0246 \\
\hline Jumlah & 463 & 1.17 & 0.67 & 1.000 & 5.7610 \\
\hline
\end{tabular}

Keterangan : $\mathrm{H}$ : Indeks Keanekaragaman, $\mathrm{E}$ : Indeks Kemerataan C : Indeks Dominansi KP :Kepadatan populasi dalam Plot $3 \mathrm{~m} \times 3 \mathrm{~m}$

Arthropoda tanah yang terinventarisasi berjumlah 11 ordo yaitu Hymenoptera, Dermaptera, Diptera, Araneae,Collembola, Acarina, Orthoptera, Scolopendomorpha, Spirobolida, Coleoptera dan blattaria. dengan 463 individu dengan frekuensi kehadiran dan kelimpahan terbanyak ada pada ordo Hymenoptera dengan indeks keanekaragam arthropoda tanah sebesar 1,17 menunjukkan indeks keanekaragaman sedang berdasarkan kriteria indeks keanekaragaman (Suwondo, 1991) indeks keanekaragaman $H<1$ kategori rendah, $1<\mathrm{H}<3$ kategori sedang dan $\mathrm{H}=3$ kategorinya tinggi berarti jika nilainya lebih dari 1 maka tingkat keanekaragamannya sedang, Indeks dominansi (C) yaitu 1,0 menunjukkan tingkat dominansi tinggi menurut odum kreterianya $\mathrm{C}<0,5=$ dominansi rendah sedangkan C> 0,5 dominansi tinggi yaitu didominasi oleh ordo Hymenoptera
Indeks Kemerataan (E) spesies yaitu 0,67 kreteria kemerataannya rendah ada dominansi spesies menurut kreteria indeks kemerataan Pielous jika $E<0,5$ Kemerataan tinggi sedangkan E> 0,5 dan kepadatan populasi 5,7610. Ekosistem dikatakan seimbang dengan demikian untuk menjadikan area konservasi kura-kura Baning komponen pendukung dalam ekosistem berupa faktorbiotik dalam hal ini arthropoda tanah sudah mendukung namun demikian tetap perlu propaganda pada civitas akademika untuk lebih peduli terhadap lingkungan terutama pengolahan sampah organik.

Berdasarkan tabel 4.2.jumlah Ordo dan individu arthropoda tanah permukaan tanah dari Ordo Hymenoptera, Collembola, dan Dermaptera lebih banyak ditemukan dibandingkan dengan ordo yang lain. Hal ini dapat disebabkan karena arthropoda tanah tersebut merupakan arthropoda tanah yang umum beraktivitas di permukaan tanah (Borror,1996)

Banyaknya jumlah Ordo arthropoda tanah yang didapatkan karena lingkungan yang sesuai untuk mendukung kehidupannya dan pengaruh komponen pendukung dalam ekosistem yang ada disekitar lahan tersebut. Keberadaan arthropoda tanah di suatu tempat tergantung dengan faktor lingkungannya yaitu abiotik (Pelawi, 2010).

Faktor abiotik yang keadaanya berbeda dan berubah sesuai dengan perbedaan tempat dan waktu. Suhu diarea konservasi kura-kura Baning Gajah $27^{\circ} \mathrm{C}$ merupakan suhu yang menguntungkan bagi biota tanah karena menurut Hanafiah,(1995) menyatakan bahwa temperatur (suhu) sangat mempengaruhi aktivitas biota tanah, laju optimum aktivitas biota tanah terjadi pada temperatur $18^{\circ} \mathrm{C}$ sampai dengan $30^{\circ} \mathrm{C}$.

Kelembaban udara dipengaruhi tegakkan pohon dengan tajuk yang rapat sehingga cahaya yang masuk kepermukaan tanah sedikit maka kelembaban udara tinggi akan menguntungkan bagi kehidupan arthropoda tanah. Dari hasil pengamatan faktor abiotik area konservasi sangat mendukung

\section{Hasil Analisis Validasi Perangkat Pembelajaran \\ Implementasi hasil penelitian Arthoropoda} Tanah di Area Konservasi kura-kura Baning Universitas Bengkulu dilanjutkan dengan pembelajaran berbasis lingkungan dengan topik 
Ekosistem yang dilakukan kedalam kegiatan pembelajaran Biologi pada peserta didik kelas X SMAN 1 Ujan Mas Kabupaten Kepahiang.

Siswa yang dilibatkan untuk uji coba berjumlah 20 orang. Instrument penelitian ini berupa LKPD dengan pendekatan lingkungan yang merupakan aplikasi penelitian keanekaragaman Arthoropda tanah di Area konservasi kura-kura Baning Universitas Bengkulu dan penilaian keterampilan berpikir kritis secara kognitif serta kinerja siswa.

Dalam penelitian ini produk yang dihasilkan adalah silabus, RPP, dan LKPD yang terlebih dahulu di validasi oleh Tenaga ahli (Akademisi) dan Praktisi (guru mata pelajaran biologi SMA). Hasil validasi menunjukkan bahwa perangkat pembelajaran layak untuk diujicobakan dengan seperti tabel 3. berikut ini:

Tabel 3: Hasil validasi rata-rata skor dan prosentase perangkat pembelajaran oleh akademisi dan praktisi.

\begin{tabular}{|l|l|c|l|r|l|}
\hline $\begin{array}{c}\text { Perangkat } \\
\text { Pembelajaran }\end{array}$ & $\begin{array}{c}\text { Aspek } \\
\text { Penilaian }\end{array}$ & $\begin{array}{c}\text { Skor } \\
\text { rata- } \\
\text { rata }\end{array}$ & Kriteria & $\begin{array}{c}\text { \% } \\
\text { nilai }\end{array}$ & Keterangan \\
\hline \multirow{5}{*}{ SILABUS } & $\begin{array}{l}\text { Kelayakan } \\
\text { isi }\end{array}$ & 25,5 & $\begin{array}{l}\text { Sangat } \\
\text { Baik }\end{array}$ & 91,07 & $\begin{array}{l}\text { Sangat } \\
\text { Layak }\end{array}$ \\
\cline { 2 - 6 } & Bahasa & 3 & Baik & 75 & Layak \\
\cline { 2 - 6 } & $\begin{array}{l}\text { Format dan } \\
\text { identitas }\end{array}$ & 7 & Baik & 87,5 & Layak \\
\hline \multirow{5}{*}{ RPP } & $\begin{array}{l}\text { Kelayakan } \\
\text { isi }\end{array}$ & 13,75 & Cukup & 68,75 & $\begin{array}{l}\text { Layak } \\
\text { dengan } \\
\text { Revisi }\end{array}$ \\
\cline { 2 - 7 } & Bahasa & 10 & Baik & 83,33 & $\begin{array}{l}\text { Layak } \\
\text { digunakan } \\
\text { tampa revisi }\end{array}$ \\
\hline \multirow{5}{*}{ LKPD } & $\begin{array}{l}\text { Kelayakan } \\
\text { isi }\end{array}$ & 10 & Baik & 86,63 & $\begin{array}{l}\text { layak } \\
\text { digunakan }\end{array}$ \\
\cline { 2 - 6 } & Bahasa & 10,5 & Baik & 87,5 & $\begin{array}{l}\text { layak } \\
\text { digunakan }\end{array}$ \\
\cline { 2 - 6 } & Penyajian & 10,25 & Baik & 83,3 & $\begin{array}{l}\text { layak } \\
\text { digunakan }\end{array}$ \\
\cline { 2 - 6 } & Kegrafisan & 12,5 & Baik & 83,3 & $\begin{array}{l}\text { layak } \\
\text { digunakan }\end{array}$ \\
\hline
\end{tabular}

Keterangan : Skala nilai : $\mathrm{K}<60$ kurang, tidak layak digunakan, $60 \leq \mathrm{c} \leq 75$ : cukup, layak digunakan dengan revisi, $75 \leq \mathrm{B} \leq 90$ Baik, layak digunakan tampa revisi dan $90 \leq \mathrm{A} \leq 100$ : Amat baik, sangat layak digunakan.

Berdasarkan kelayakan isi pada silabus dinilai sangat baik, sedangkan bahasa dan format identitas dinilai baik sedangkan pada RPP kelayakkan isi bernilai cukup dan LKPD dinilai baik dan layak digunakan tanpa revisi. Pada lembar validasi untuk kesempurnaan perangkat pembelajaran akademisi memberikan saran agar RPP diperjelas kembali penyusunan sesuai dengan kegiatan yang akan dilakukan dan kurikulum yang telah ditetapkan, perumusan langkah dalam pembelajaran perlu ditulis secara runut,logis, efektif dan efisien dan mempermudah tindakan yang akan dilakukan serta perlu perbaikan bahasa sesuai dengan EYD

Komponen dalam LKPD perlu perbaikan dalam kelayakkan isi yaitu : materi pembelajaran jangan terlalu dangkal karena tidak dapat menyajikan informasi yang dibutuhkan dalam kegiatan pembelajaran serta komponen kegrafisan perlu diperbaiki proporsi warna latar belakang jangan sampai menutupi tulisan sehingga menghalangi siswa untuk membaca dan memahami soal atau materi, peneliti mengikuti saran dari akademisi untuk memperbaiki komponen perangkat pembelajaran, yaitu pada materi yang masih dangkal peneliti menambahkan penjelasan mengenai komponenkomponen penyusun dalam ekosistem serta hubungan antara setiap komponen dalam ekosistem tersebut agar lebih jelas dan peserta didik dapat lebih memahami dan gambar latar belakang pada gambar yang warnanya lebih mencolok penulis menggantikaanya dengan warna putih agar tidak mengganggu tulisan yang akan dibaca peserta didik. Setelah diperbaiki perangkat pembelajaran diujicobakan pada skala kecil di SMA negeri 1 Ujan Mas.

\section{Hasil Analisis Uji Coba Skala Kecil Penilaian Kemampuan Berpikir Kritis}

Data hasil penelitian dilakukan dalam dua tahapan yaitu di SMAN 1 Ujan Mas pada kelas X dengan jumlah peserta didik 20 orang pada materi Ekosistem dan submateri Komponen penyusun dalam ekosistem dan pelaksanaan pembelajaran berbasis lingkungan untuk menilai kemampuan berpikir kritis pada aspek kognitif dan kinerja siswa dilakukan di Area konservasi kura-kura Baning Universitas Bengkulu diperoleh hasil seperti pada grafik dibawah ini. 


\section{Grafik 1 . Presentase kemampuan berpikir kritis pada aspek kognitif peserta didik}

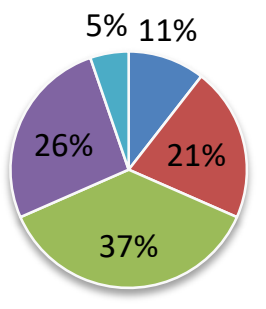

$$
\begin{aligned}
& \text { (sangat kurang } \\
& \text { kritis) } \\
& \text { - kurang kritis } \\
& \text { cukup kritis }
\end{aligned}
$$

Gambar 1. Presentase kemampuan berfikir kritis pada aspek kogniif

Dari analisis uji coba skala kecil tentang kemampuan berpikir kritis secara kognitif dan kinerja berpikir kritis diperoleh data yaitu 5\% pada interval 51-60 dengan kategori sangat kurang kritis, $21 \%$ pada interval 61-70 dengan kategori kurang kritis , 37\% pada interval 71-80 kategori cukup kritis, 26\% pada interval 81-90 kategori kritis , 11\% pada interval 91-100 dengan kategori sangat kritis . Berdasarkan data tersebut dapat diketahui bahwa tingkat ketercapaian peserta didik dengan kreteria sangat baik (A) 86100,71-85 kreteria sedang dan kreteria rendah kurang dari 70 , (permendikbud nomor 53 tahun 2015). Penilaian keterampilan berpikir secara kognitif dan kinerja berpikir kritis termasuk kreteria sangat baik $11 \%$, sedang dan tinggi $26 \%$ rendah $26 \%$. Hasil data ini penulis kelompokkan lagi secara klasikal peserta didik kelompokkan dalam dua kategori yaitu kritis dan kurang kritis memperoleh hasil seperti pada grafik berikut ini.

\section{Grafik.2 Presentase Kemampuan Berpikir Kritis Pada Aspek Kognitif Peserta didik}

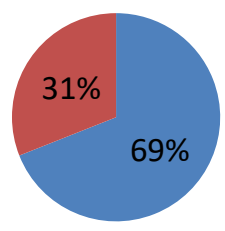

kritis nurang kritis

Gambar 2. Presentase kemampuan berfikir kritis pada aspek kognitif

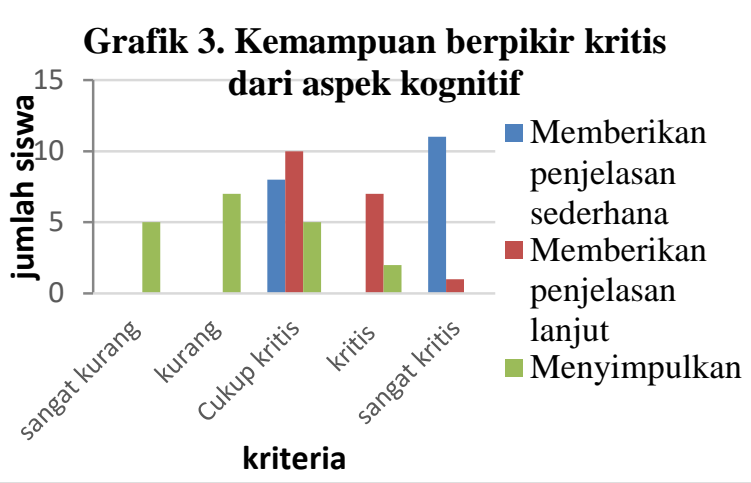

Gambar 3. Kemampuan berfikir kritis dari spek kognitif

Berdasarkan Grafik diatas peneliti membagi aspek kinerja dalam dua kelompok kritis dan kurang kritis secara klasikal diperoleh hasil prentase sebagai berikut:

\section{Grafik 4. Presentase Kemampuan berpikir kritis pada aspek kinerja}

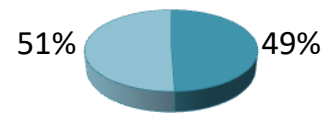
Keterampilan dasar

Gambar 4. Presentase kemampuan berfikir kritis pada aspek kinerja

Berdasarkan analisis data penelitian menunjukkan bahwa secara keseluruhan kemampuan berpikir kritis siswa SMA Negeri 1 Ujan Mas di Kabupaten Kepahiang tergolong kritis baik pada keterampilan dasar maupun pada mengatur strategi hal ini terlihat dari hasil yang diperoleh peserta didik pada saat pelaksanaan pembelajaran berbasis lingkungan dengan kritis sampai sangat kritis pada aspek (1) Memberikan penjelasan sederhana (2) Membangun keterampilan dasar (3) Memberikan penjelasan lanjut (4) Mengatur strategi dan taktik tetapi kurang pada aspek (5) Menyimpulkan terutama menyimpulkan dari mendeduksi.

Berdasarkan uraian diatas kemampuan berpikir kritis peserta didik SMA Negeri 1 Ujan Mas dapat ditumbuhkan dengan pembelajaran berbasis lingkungan dimana peserta didik dapat melihat langsung arthropoda tanah dan bagaimana arthropoda tanah itu berinteraksi langsung dengan komponen abiotiknya. Dengan demikian peserta didik dapat menghubungkan 
apa yang akan terjadi jika komponen abiotik dan biotik mengalami gangguan.

Erat kaitannya dengan keaktifan siswa dalami belajar adalah suatu dorongan internal dan eksternal yang mendorong individu untuk berbuat sehingga perubahan tingkah laku dalam diri siswa untuk belajar meningkat. Selanjutnya berdasarkan hasil observasi peserta didik dapat menemukan dengan sendiri dan manjawab berdaskan fakta-fakta yang ada sehingga mampu merumuskan dan menyelesaikan masah yang sehingga mampu berpikir kritis karena sebelumnya siswa SMA Negeri 1 Ujan Mas jarang melakukan pembelajaran berbasis lingkungan di luar kelas sehingga ketika diajak ke Area Konservasi Kura-kura Baning Universitas Bengkulu mendorong siswa belajar dengan senang dan bersungguh-sungguh, lebih berhati-hati dalam menggunakan alat. Menurut Fisher (2009) dalam vandalita mengungkapkan bahwa kemampuan berpikir kritis dapat mempengaruhi hasil belajar siswa, kemampuan bepikir kritis dapat menggali dan memadukan fakta-fakta, prinsip, konsep, dan teori sehingga materi pelajaran yang dipelajari menjadi bermakna.

\section{KESIMPULAN}

1. Jenis Arthropoda tanah yang ditemukan di Area Konservasi Kura-kura Baning Universitas Bengkulu berjumlah 11 ordo

2. Keanekaragaman jenis arthropoda tanah yang diperoleh dari Area Konservasi Kura-kura Baning tergolong dalam kategori sedang dan ada spesies yang mendominasi yang tergolong dalam ordo Hymenoptera.

3. Keadaan faktor abiotik pada Area Konservasi Kura-kura Baning termasuk kedalam kategori normal dengan ekosistem yang seimbang

4. Perangkat pembelajaran berbasis lingkungan yang dirancang termasuk kedalam kategori sangat layak digunakan untuk mengukur kemampuan berpikir kritis siswa

5. Kemampuan berpikir kritis peserta didik dari aspek kinerja termasuk kedalam dua kriteria yaitu sangat kritis dan kritis dengan persentasi nilai tertinggi terdapat pada dimensi membangun keterampilan dasar dengan indikator mengobservasi dan mempertimbangkan hasil observasi, sedangkan dari aspek kognitif termasuk kedalam 4 kriteria yaitu sangat kritis, kritis, cukup kritis, dan kurang kritis dan dengan persentase nilai tertinggi pada dimensi memberikan penjelasan sederhana dan memberikan penjelasan lanjut.

\section{DAFTAR PUSTAKA}

Arief, A. (2001). Hutan \& kehutanan. Kanisius. Borror, D. J; C. A. Tripleron, N. F. Jhonson. (1996). Pengenalan Pelajaran Serangga. Terjemahan oleh S. Partosoedjono. Yogyakarta: Gadjah Mada University Press.

Dick, W., Carey, L., \& Carey, J. O. (2005). The systematic design of instruction.

Hanafiah, A. (1995). Peningkatan Nilai Nutrisi Empulur Sagu (Metroxylon sp) sebagai Bahan Pakan Monogastrik melalui Teknologi Fermentasi Menggunakan Aspergillus niger. Skripsi. IPB, Bogor, Indonesia.

Pelawi, A. P. (2010). Indeks Keanekaragaman Jenis Serangga Pada Beberapa Ekosistem Di Areal Perkebunan PT. Umbul Mas Wisesa Kabupaten Labuhanbatu. Indeks Keanekaragaman Jenis Serangga Pada Beberapa Ekosistem Di Areal Perkebunan PT. Umbul Mas Wisesa Kabupaten Labuhanbatu.

Silviana, F. (2014). Perancangan dan Implementasi Aplikasi Pembelajaran Kingdom Animalia Sekolah Menengah Atas (SMA) pada Platform Android (Doctoral dissertation, Program Studi Teknik Informatika FTI-UKSW).

Suwondo, Elya Febrita,Andri Hendrizal, (2015). Komposisi dan Komposisi dan Keanekaragaman Serangga Tanah Di Arboretum Universitas Riau sebagai Sumber Belajar Melalui Model Inkuiri, Jurnal Biogenesis Vol.11 (2): 93-98,2015: Program Biologi FKIP Universitas Riau ISSN : 1829 5460.

Tarumingkeng, R. C. (2003). Serangga dan Lingkungan.

Winarni, E.W. (2012). Inovasi Dalam Pembelajaran IPA.Bengkulu : FKIP Universitas Bengkulu 